\title{
Regulation of microbial carbon, nitrogen, and phosphorus transformations by temperature and moisture during decomposition of Calluna vulgaris litter
}

\author{
M. J. M. Van Meeteren • A. Tietema • J. W. Westerveld
}

Received: 10 April 2006 /Revised: 1 February 2007 / Accepted: 5 February 2007 / Published online: 1 March 2007

(C) Springer-Verlag 2007

\begin{abstract}
To evaluate the effect of climate change on ecosystem functioning, the temperature and moisture response of microbial $\mathrm{C}, \mathrm{N}$, and $\mathrm{P}$ transformations during decomposition of Calluna vulgaris (L.) Hull. litter was studied in a laboratory incubation experiment. The litter originated from a dry heathland in the Netherlands where P limited vegetation growth. Fresh litter was incubated at 5, 10,15 , or $20^{\circ} \mathrm{C}$ and at a moisture content of 50,100 , or $200 \%$ in a full factorial design. Microbial nutrient transformations and activity were evaluated during two successive periods: an initial period of 48 days characterized by microbial growth and a second period from 48 to 206 days in which microbial growth declined significantly. Temperature and moisture response of respiration rate, the metabolic quotient $\left(q \mathrm{CO}_{2}\right), \mathrm{C}, \mathrm{N}$, and $\mathrm{P}$ immobilization, net $\mathrm{N}$ and $\mathrm{P}$ mineralization and nitrification rates were evaluated by performing linear regressions. Microbial nutrient transformations and microbial activity depended both on temperature and moisture. In the first period, the respiration rate, $q \mathrm{CO}_{2}$, microbial $\mathrm{C}$ and $\mathrm{N}$ immobilization, net $\mathrm{P}$ mineralization, net $\mathrm{N}$ mineralization and net nitrification rates were more strongly affected by temperature, while the microbial $\mathrm{P}$ immobilization rate was more strongly
\end{abstract}

M. J. M. Van Meeteren · A. Tietema $(\bowtie) \cdot J$. W. Westerveld Centre for Geo-ecological Research (ICG),

Institute for Biodiversity and Ecosystem Dynamics (IBED),

Universiteit van Amsterdam,

Nieuwe Achtergracht 166,

NL-1018 WV Amsterdam, The Netherlands

e-mail: atietema@science.uva.nl

Present address:

M. J. M. Van Meeteren

Haskoning Nederland B.V.,

P.O. Box 8520, 3009 AM,

Rotterdam, The Netherlands affected by moisture. The respiration rate, $q \mathrm{CO}_{2}, \mathrm{P}$ immobilization rate, net $\mathrm{P}$ and $\mathrm{N}$ mineralization rate, and nitrification rate increased with temperature and moisture, while the $\mathrm{C}$ and $\mathrm{N}$ immobilization rate decreased with increasing temperature and increased with moisture. In the second period, $\mathrm{C}, \mathrm{N}$, and $\mathrm{P}$ immobilization and net $\mathrm{N}$ and $\mathrm{P}$ mineralization rates were significantly lower. The respiration rate and $q \mathrm{CO}_{2}$ continued to increase with temperature and moisture, but $\mathrm{C}$ and $\mathrm{N}$ immobilization rates increased with temperature and declined with increasing moisture. Net $\mathrm{P}$ mineralization rate decreased at higher temperature and moisture, and nitrification rate declined with increasing temperature and increased with moisture. It was concluded that plant growth in these P-limited systems is very sensitive to climate change as it strongly relies on the competition for $\mathrm{P}$ with microbes, and temperature and moisture have a large effect on the immobilization rate of available P.

Keywords Decomposition · Temperature · Moisture · Immobilization $\cdot$ Mineralization

\section{Introduction}

Temperature and moisture are key factors regulating biogeochemical processes such as litter decomposition (Kirschbaum 1995), respiration (e.g. Howard and Howard 1993; Leirós et al. 1999), nutrient mineralization, and immobilization (Schmidt et al. 1999; Jonasson et al. 2004). The respiration rate and net $\mathrm{N}$ mineralization rate have been reported to show an increase, no response, or even a decrease with higher temperatures (Rustad et al. 2001). It is thought that the lack of response or negative response is related to a simultaneous decline in moisture content associated with increasing temperature (Peterjohn et al. 
1994; McHale et al. 1998; Rustad and Fernandez 1998), as well as the availability of nutrients. For example, several studies have reported limited response of plant growth to warming alone, but significant response to warming plus fertilization (Parsons et al. 1994; Wookey et al. 1994; Press et al. 1998; Jonasson et al. 1999).

The Dutch heathland ecosystem 'Oldebroekse heide' has been subjected to climate manipulations since May 1999. The manipulations involved nighttime warming or summer drought in $20-\mathrm{m}^{2}$ plots (Beier et al. 2004). The ecosystem is $\mathrm{N}$-saturated, as atmospheric $\mathrm{N}$ deposition in the Netherlands has exceeded critical loads of $15-20 \mathrm{~kg} \mathrm{~N}^{-1}$ year $^{-1}$ for half a century (Heil and Bobbink 1993), and nitrate leaching is high at the site (Schmidt et al. 2004). The highly weathered acid sandy soil is mineralogically very poor with very low inorganic $\mathrm{P}$ concentrations in the soil solution (Schmidt et al. 2004). The dominating plant Calluna vulgaris (L.) Hull. produces P-poor litter with an N/P $(g / g)$ ratio of $>16$, indicating that $P$ is limiting vegetation growth (Koerselman and Meuleman 1996). Because of the low $P$ availability in mineral soil, $\mathrm{P}$ mineralization through organic matter decomposition is an important $\mathrm{P}$ source for plants and microorganisms.

Litter produced is $\mathrm{P}$-poor and $\mathrm{P}$ competition between plants and microorganisms is therefore likely to be strong. As a result, the microbial community plays an important role in litter decomposition and nutrient mineralization and immobilization (Kirschbaum 1995; Dilly and Munch 1996; Schmidt et al. 1999; Jonasson et al. 2004). Highest fluxes between organic litter $\mathrm{P}$, microbial immobilized $\mathrm{P}$, and inorganic $\mathrm{P}$ occurred during the initial stage of $C$. vulgaris litter decomposition (Van Meeteren 2005). In a preliminary study, we identified two stages during this initial decomposition. The first period of about 50 days of microbial growth when 81 to $89 \%$ of total P was immobilized and a second period from about 50 to 200 days in which microbial growth decreased significantly as a result of litter $\mathrm{P}$ depletion and consequently low $\mathrm{P}$ availability for microbial immobilization.

The objective of this study was to determine the effect of climate change on $\mathrm{C}, \mathrm{N}$, and $\mathrm{P}$ transformations during these two stages of decomposition of C. vulgaris litter. Climate change might affect microbial dynamics for instance by different sensitivity of the microbes involved. This could change the rates of the fluxes between the $\mathrm{P}$ pools, which could affect future $\mathrm{P}$ availability for the Calluna plants in this semi-natural ecosystem.

\section{Materials and methods}

Sampling and litter preparation

Litter was collected at the Dutch heathland site called 'Oldebroekse heide' $\left(52^{\circ} 25 \mathrm{~N}, 5^{\circ} 53 \mathrm{E}\right)$ located in the center of the Netherlands (Beier et al. 2004). The soil is a nutrientpoor, well-drained, acid sandy Haplic Podzol (FAO 1998) with a mormoder humus form (Green et al. 1993). The heathland is dominated by the dwarf shrub $C$. vulgaris with an average age of 15 years. The $C$. vulgaris vegetation forms a dense, intertwined canopy. Ready-to-fall Calluna litter, consisting of shoots, flowers, and branches (under $1.5 \mathrm{~mm}$ in diameter and under $20 \mathrm{~mm}$ in length $(40 \mathrm{~mm}$ for branches), was collected in autumn 2001 by lifting the plants and placing a plastic sheet underneath.

The shrubs were gently shaken and senesced litter was collected. Part of the litter we collected had been in direct contact with the soil surface and therefore further inoculation with soil extracts of microflora and microfauna was not necessary. The collected litter was taken to the laboratory where it was left in the open air in the laboratory at $20^{\circ} \mathrm{C}$ to let macrofauna escape. The material was uniformly mixed and stored in plastic bags at $3{ }^{\circ} \mathrm{C}$. Litter consisted of $56 \%$ flowers, $27 \%$ shoots, and $4 \%$ branches (on a mass basis); the remainder consisted of small unidentifiable particles.

Initial chemical composition of the bulked litter was $543 \mathrm{~g} \mathrm{C} \mathrm{kg}^{-1}, 11.81 \mathrm{~g} \mathrm{~N} \mathrm{~kg}^{-1}, 0.61 \mathrm{~g} \mathrm{P} \mathrm{kg}^{-1}, 3.53 \mathrm{~g} \mathrm{Ca} \mathrm{kg}^{-1}$, and $0.20 \mathrm{~g} \mathrm{Mn} \mathrm{kg}^{-1}$. The initial $\mathrm{C} / \mathrm{N}$ and $\mathrm{N} / \mathrm{P}$ ratio $\left(\mathrm{g} \mathrm{g}^{-1}\right)$ was 46 and 19, respectively, and the lignin concentration was $393 \mathrm{~g} \mathrm{~kg}^{-1}$.

\section{Incubation experiment}

Fifteen grams of litter were weighed in petri dishes $(14 \mathrm{~cm}$ diameter $\times 1.2 \mathrm{~cm}$ height) and moisture was adjusted to 50 , 100 , or $200 \%\left(0.5,1.0\right.$, and $2.0 \mathrm{~g}$ water $\mathrm{g}^{-1}$ dry litter, respectively) on a mass basis, representing realistic field moisture contents of the organic layer. The petri dishes were closed with a loosely fitting cover to allow aeration for microbial respiration and put in a tray in an incubator at $5,10,15$, or $20^{\circ} \mathrm{C}$. Small jars filled with water together with moist tissue paper were also placed in the incubator and the whole was loosely covered by a plastic sheet to provide a moist atmosphere. The experimental design was full factorial, with temperature and moisture as factors, with four and three levels, respectively, making up 12 treatments, each treatment with five replicates per time step. Evaporation was compensated weekly by adding deionized water to maintain constant moisture content.

Litter weight loss was determined on five replicate samples after 48, 80, 108, and 206 days for each treatment. The addition of water was adjusted to this weight loss. Initial microbial and chemical characterization of the litter material was performed before the addition of water (day 0 ) on five replicate samples. After 48 and 206 days of incubation, five replicate samples per treatment were removed from the incubator and analyzed. 
To measure the $\mathrm{CO}_{2}$ production rate the samples were placed in Mason jars and the samples were incubated for one night at the same conditions of the incubation treatment. This pretreatment was done to make sure that the respiration rate measurement the next day was not influenced by moving the samples. The next day the jars were aerated and closed airtight. The headspace was sampled after 0,3 , and $6 \mathrm{~h}$ using a gas-tight syringe and a septum in each jar. The collected sample was immediately injected in a Carlo Erba gas chromatograph to quantify the $\mathrm{CO}_{2}$ concentration. The difference between the headspace $\mathrm{CO}_{2}$ concentration divided by the time between measurements was considered the respiration rate. Then the litter in the jars was split into several subsamples for further analysis.

Moisture content was determined by drying a subsample at $70^{\circ} \mathrm{C}$ for $48 \mathrm{~h}$. Microbial biomass $\mathrm{C}$ and $\mathrm{N}$ were determined by fumigating a moist subsample corresponding to $1.5 \mathrm{~g}$ dry litter for $24 \mathrm{~h}$ with ethanol-free $\mathrm{CHCl}_{3}$, then extracted with $0.5 \mathrm{M} \mathrm{K}_{2} \mathrm{SO}_{4}$ (for $1 \mathrm{~h}$ ) (Brookes et al. 1985; Vance et al. 1987). At the same time, a non-fumigated subsample was extracted with $0.5 \mathrm{M} \mathrm{K}_{2} \mathrm{SO}_{4}$. Extracts were analyzed for dissolved organic $\mathrm{C}$ (DOC), total $\mathrm{N}$, $\mathrm{N}-\mathrm{NH}_{4}^{+}, \mathrm{N}-\mathrm{NO}_{3}^{-}$, and $\mathrm{N}-\mathrm{NO}_{2}^{-}$on a Skalar continuous flow auto-analyzer; so dissolved organic $\mathrm{N}$ (DON) concentrations could be calculated. Microbial biomass $\mathrm{C}$ was estimated as the difference between the DOC concentration of the fumigated and unfumigated extracts. Microbial biomass $\mathrm{N}$ was estimated as the difference between the summed DON, $\mathrm{N}-\mathrm{NH}_{4}^{+}$and $\mathrm{N}-\mathrm{NO}_{3}^{-}\left(\mathrm{N}-\mathrm{NO}_{2}^{-}\right.$was not present) concentration of the fumigated and unfumigated extracts. Because of analytical problems DON was not measured at day 0 . The DON was part of the lysed microbial biomass after fumigation, but the size of the microbial biomass $\mathrm{C}$ at day 0 was very small, indicating that DON could never be a substantial part of the lysed microbial N. An extractability of 0.45 was assumed when calculating the microbial C and N (Wu et al. 1990).

Inorganic $\mathrm{P}\left(\mathrm{P}_{\mathrm{i}}\right)$ was analyzed by shaking a moist subsample corresponding to $0.5 \mathrm{~g}$ of dry litter with $50.0 \mathrm{ml} 0.5 \mathrm{M} \mathrm{NaHCO}_{3}(\mathrm{pH} 8.5$, for $30 \mathrm{~min}$ ) (Olsen et al. 1954). The resulting solution was filtered and solution $\mathrm{P}$ concentrations were determined colorimetrically by the ammonium molybdate ascorbic acid method as described by Murphy and Riley (1962). Microbial biomass P was determined by the fumigation extraction method as described by Brookes et al. (1982). A moist subsample corresponding to $0.5 \mathrm{~g}$ of dry litter was fumigated for $24 \mathrm{~h}$ with $\mathrm{CHCl}_{3}$ and extracted with $50.0 \mathrm{ml} 0.5 \mathrm{M} \mathrm{NaHCO}_{3}$ (pH 8.5, for $30 \mathrm{~min}$ ). In the extract inorganic $\mathrm{P}$ concentration was also determined colorimetrically by the ammonium molybdate ascorbic acid method. Microbial biomass P was calculated as the difference between the $\mathrm{P}$ concen- trations of the fumigated and unfumigated extract. An extractability of 0.40 for $\mathrm{P}$ was assumed (Brookes et al. 1982). Total P content was measured on ICP-OES (Optima 3000XL, Perkin Elmer) after an $\mathrm{HNO}_{3}+\mathrm{HCl}$ digestion $\left(4.0 \mathrm{ml} \mathrm{HNO}_{3} 65 \%, 1.0 \mathrm{ml} \mathrm{HCl} 37 \%\right.$, and $1.0 \mathrm{ml} \mathrm{H}_{2} \mathrm{O}$ ) of a 250.0-mg sample (ground and homogenized: $<0.2 \mathrm{~mm}$ ) in a microwave oven (Multiwave, Anton Paar).

\section{Calculations}

Microbial $\mathrm{C}, \mathrm{N}$, and $\mathrm{P}$ immobilization, net $\mathrm{N}$ and $\mathrm{P}$ mineralization and nitrification, respiration rate, and the metabolic quotient $\left(q \mathrm{CO}_{2}\right)$ (Anderson and Domsch 1990) were calculated for the first ( 0 to 48 days) and second incubation period (48 to 206 days). Microbial C, N, and P immobilization, net $\mathrm{N}$ and $\mathrm{P}$ mineralization and nitrification were calculated as the difference in sample microbial $\mathrm{C}, \mathrm{N}$, and $\mathrm{P}, \mathrm{N}-\mathrm{NH}_{4}^{+}$plus $\mathrm{N}-\mathrm{NO}_{3}^{-}, \mathrm{P}_{\mathrm{i}}$, and $\mathrm{N}-\mathrm{NO}_{3}$ (no $\mathrm{NO}_{2}^{-}$ was found) concentration in milligram per kilogram (mg $\mathrm{kg}^{-1}$ ) between days 0 and 48 and between days 48 and 206, divided by the number of days (Schmidt et al. 1999). The respiration rate was calculated as the average respiration rate in milligram $\mathrm{C}$ per kilogram per day $\left(\mathrm{mg} \mathrm{C} \mathrm{kg}^{-1}\right.$ day $\left.^{-1}\right)$ during the two incubation intervals. The $q \mathrm{CO}_{2}$ was calculated as the average $\mathrm{C}-\mathrm{CO}_{2}$ respiration rate per gram microbial C per hour (mg C- $-\mathrm{CO}_{2}[\text { g microbial C }]^{-1} \mathrm{~h}^{-1}$ ) between days 0 and 48 and between days 48 and 206.

\section{Regression analysis}

The effect of temperature $(T)$ and moisture $(M)$ on the measured variables was evaluated by performing a linear regression for each incubation period, with temperature and moisture as the independent variables. The linear regression was performed with the SPSS Linear Regression procedure (SPSS Inc. 2001). Data fitted best to the following linear Eq. (1):

$Y=i+t^{*} T+m^{*} M$

where $Y$ is the dependent variable, $i$ the intercept, and $t$ and $m$ the coefficients for $T$ (temperature in degree Celsius) and $M$ (moisture in percent). The regression coefficients $t$ and $m$, a two-tailed significance level of these coefficients, and the $r^{2}$ of the linear regression were estimated. Because temperature increased with 15 units from 5 to $20^{\circ} \mathrm{C}$ and moisture with 150 units from 50 to $200 \%$, the moisture percentage had to be divided by 10 to obtain the same increase to evaluate the relative impact of temperature (slope $t$ ) and moisture (slope $m$ ) on a variable. When $t>m$, temperature is the most important factor explaining the variation in the data, and when $m>t$, moisture is the most important factor explaining the variation in the data. The sign of $t$ and $m$ (plus or minus) indicated whether a variable increased (plus) with 
increasing temperature or moisture or decreased (minus) with increasing temperature or moisture condition.

\section{Decomposition rate}

The decomposition rate constant $k$ was calculated from the proportion of dry litter remaining in petri dishes after 0,48 , 80,108 , and 206 days, using the negative exponential decay function (2):

$X_{t}=X_{0}^{*} e^{-k t}$,

where $X_{t}$ is the mass litter left at time $t(\mathrm{~g}), X_{0}$ the initial amount of litter mass (g), $t$ time (years), and $k$ fractional weight loss (year ${ }^{-1}$ ) (Swift et al. 1979).

Statistical analysis

Data were tested for homogeneity of variance using Levene's homogeneity of variance test (Levene 1960). Two-way analysis of variance was performed with temperature (5, 10,15 , and $\left.20^{\circ} \mathrm{C}\right)$ and gravimetric moisture content (50, 100 , and $200 \%$ ) as factors. A post hoc multiple comparisons test was used to test which decomposition rate constants $(k)$ differed, using Tukey's honestly significant difference tests in case of equal variances and a Tamhane's T2 test in case of unequal variances. Differences in means were called significant when $P<0.05$. Tests were performed with the SPSS General Linear Model procedure (SPSS 2001) using type III sums of squares. Data are reported as means \pm SD.

\section{Results}

Treatment effect

Temperature and moisture had a significant effect on all variables in the first decomposition period, except for temperature on microbial $\mathrm{P}$ immobilization and moisture on microbial $\mathrm{C}$ immobilization, where the effect was weakly significant (Table 1). In the second period, temperature had a significant effect on all variables, while moisture had no effect on net P mineralization and only a weakly significant effect on microbial $\mathrm{N}$ immobilization (Table 1).

\section{Temperature and moisture response}

In the first period, the linear regressions described the data well (Eq. 1). The $r^{2}$ values varied between 0.399 and 0.713 , explaining high proportions of the total variation in a variable by temperature and moisture (Table 2). In the second period, linear regression gave good fits for respiration and $q \mathrm{CO}_{2}$. The other regressions had very low $r^{2}$ values and were not significant for microbial $\mathrm{P}$ immobilization and net $\mathrm{N}$ mineralization and weakly significant for net nitrification. Nonlinear regression models were also used to fit the data in this period, but also these models gave very poor results (data not shown).

\section{Litter decomposition}

In general, percentage weight remaining decreased with increasing temperature and increasing moisture (Fig. 1). Decomposition rate $k$ values (Eq. 2) ranged from 0.09 year $^{-1}$ at $5^{\circ} \mathrm{C}$ and $50 \%$ moisture to 0.57 year $^{-1}$ at $20^{\circ} \mathrm{C}$ and $200 \%$ moisture (Table 3 ).

\section{Respiration rate and $q \mathrm{CO}_{2}$}

The respiration rate increased with temperature and moisture, although the effect of temperature was stronger than the effect of moisture (Table 2). Both periods showed a similar response. At $50 \%$ moisture, respiration rate increased strongest between 15 and $20^{\circ} \mathrm{C}$ (Fig. 2a,b) and at 100 and

Table 1 ANOVA for temperature and moisture effect during the first period (0-48 days) and the second period (48-206 days)

\begin{tabular}{|c|c|c|c|c|c|c|c|c|}
\hline & $\mathrm{CO}_{2}$ & $\mathrm{qCO}_{2}$ & MicroC & MicroN & MicroP & $\mathrm{P} \min$ & $\mathrm{N}$ min & Nitr \\
\hline \multicolumn{9}{|l|}{ Temperature } \\
\hline $0-48$ days & $* * * *$ & $* * * *$ & $* * * *$ & $* * * *$ & $*$ & $* * * *$ & $* * * *$ & $* * * *$ \\
\hline 48-206 days & $* * * *$ & $* * * *$ & $* * * *$ & $* * * *$ & $* * * *$ & $* * * *$ & $* * * *$ & $* * * *$ \\
\hline \multicolumn{9}{|l|}{ Moisture } \\
\hline 0-48 days & $* * * *$ & $* * *$ & $*$ & $* * * *$ & $* * * *$ & $* * *$ & $* * * *$ & $* * *$ \\
\hline 48-206 days & $* * * *$ & $* * *$ & $* * *$ & $*$ & $* *$ & & $* * * *$ & $* * *$ \\
\hline
\end{tabular}

$\mathrm{CO}_{2} \mathrm{C}-\mathrm{CO}_{2}$ respiration rate, $q \mathrm{CO}_{2}$ metabolic quotient, microC microbial $\mathrm{C}$ immobilization rate, microN microbial $\mathrm{N}$ immobilization rate, microP microbial $\mathrm{P}$ immobilization rate, $P$ min net $\mathrm{P}$ mineralization rate, $N$ min net $\mathrm{N}$ mineralization rate, nitr nitrification rate

$* P<0.1$

$* * P<0.05$

$* * * P<0.01$

$* * * * P<0.001$

Blank cells $P>0.1$ 
Table 2 Linear regression $Y=i+t * T+m * M$ (Eq. 1), $r^{2}$, and significance for the periods $0-48$ and 48-206 days
$* P<0.1$

$* * P<0.05$

$* * * P<0.01$

$* * * * P<0.001$

Blank cells $P>0.1$

\begin{tabular}{lllllll}
\hline Variable (Y) & Period & Intercept (i) & $t$ & $m$ & $r^{2}$ & Significance \\
\hline Resp & $0-48$ & 162 & 24.87 & 15.1 & 0.594 & $* * * *$ \\
& $48-206$ & 537 & 25.09 & 18.9 & 18.9 & $* * * *$ \\
$q \mathrm{CO}_{2}$ & $0-48$ & $-1.3 \times 10^{-3}$ & $6.72 \times 10^{-3}$ & $1.7 \times 10^{-3}$ & 0.622 & $* * * *$ \\
& $48-206$ & $-8.5 \times 10^{-3}$ & $8.57 \times 10^{-3}$ & $3.1 \times 10^{-3}$ & 0.575 & $* * * *$ \\
MicroC & $0-48$ & 247 & -9.53 & 1.6 & 0.429 & $* * * *$ \\
& $48-206$ & 11.2 & 0.72 & -1.1 & 0.163 & $* * *$ \\
MicroN & $0-48$ & 26.1 & -1.12 & 0.3 & 0.679 & $* * * *$ \\
& $48-206$ & -0.3 & 0.21 & $-8.1 .10^{-2}$ & 0.157 & $* * *$ \\
MicroP & $0-48$ & 2.5 & $2.70 \times 10^{-2}$ & 0.3 & 0.685 & $* * * *$ \\
& $48-206$ & 0.4 & $2.33 \times 10^{-2}$ & $2.9 \times 10^{-2}$ & 0.071 & \\
P min & $0-48$ & $1.1 \times 10^{-2}$ & $5.23 \times 10^{-2}$ & $1.3 \times 10^{-2}$ & 0.461 & $* * * *$ \\
& $48-206$ & 0.4 & $-1.69 \times 10^{-2}$ & $-4.2 \times 10^{-3}$ & 0.120 & $* *$ \\
N min & $0-48$ & 0.3 & 0.31 & -0.2 & 0.713 & $* * * *$ \\
& $48-206$ & 0.6 & $-4.69 \times 10^{-2}$ & $6.4 \times 10^{-2}$ & 0.073 & \\
Nitr & $0-48$ & -0.5 & $4.93 \times 10^{-2}$ & $3.0 \times 10^{-2}$ & 0.399 & $* * * *$ \\
& $48-206$ & $-1.7 \times 10^{-2}$ & $-4.91 \times 10^{-3}$ & $1.5 \times 10^{-2}$ & 0.085 & $*$ \\
& & & & & & \\
\hline
\end{tabular}

$200 \%$ moisture the respiration rates were approximately equal between 5 and $15^{\circ} \mathrm{C}$ and increased between 15 and $20^{\circ} \mathrm{C}$. The $q \mathrm{CO}_{2}$ showed a comparable response with temperature and moisture as the respiration rate (Table 2; Fig. 2c,d).

\section{Microbial C, N, and $\mathrm{P}$ immobilization rates}

In the first decomposition period, microbial $\mathrm{C}$ and $\mathrm{N}$ immobilization were more strongly affected by temperature, while microbial $\mathrm{P}$ immobilization was more strongly affected by moisture (Table 2). Microbial $\mathrm{C}$ and $\mathrm{N}$ immobilization rate generally decreased with increasing temperature, but increased with moisture. Both microbial C

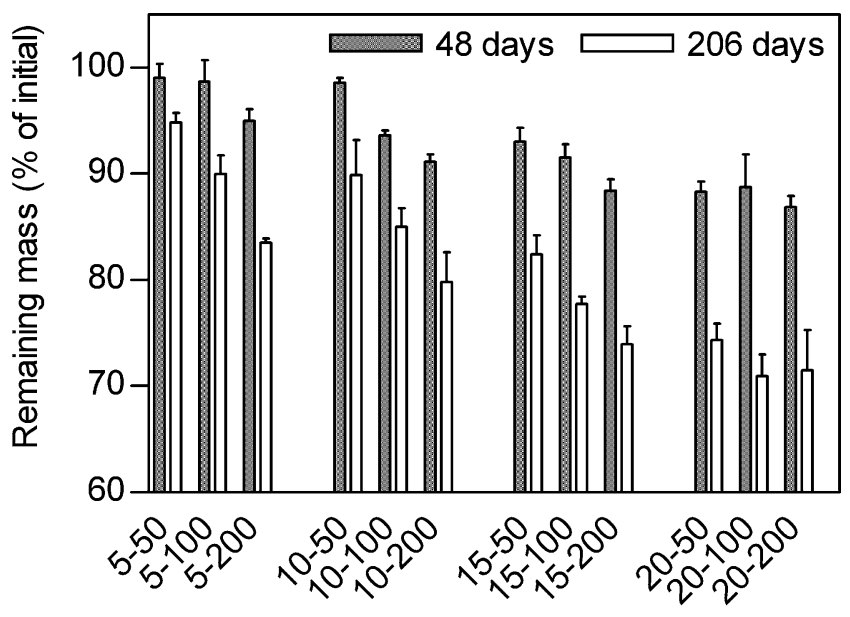

Temperature $\left({ }^{\circ} \mathrm{C}\right)$ and moisture (\%)

Fig. 1 Remaining mass as percentage of initial at 48 and 206 days of incubation. Temperature and moisture conditions are abbreviated in the following way, e.g., $5^{\circ} \mathrm{C}$ and $50 \%$ moist, is referred to as $5-50$ and similarly for the other temperature-moisture combinations. Error bars indicate standard deviation $(n=5)$ and $\mathrm{N}$ immobilization showed the same trend: microbial immobilization decreased between $5^{\circ} \mathrm{C}$ and $15^{\circ} \mathrm{C}$ and increased slightly between $15^{\circ} \mathrm{C}$ and $20^{\circ} \mathrm{C}$ (Fig. 3a,c). Considerable differences in microbial $\mathrm{P}$ immobilization rate between the three moisture levels were found: microbial $\mathrm{P}$ immobilization rate almost doubled at $200 \%$ moisture in comparison to $50 \%$ moisture (Fig. 3e).

In the second period, microbial $\mathrm{C}, \mathrm{N}$, and $\mathrm{P}$ immobilization rates decreased significantly (Fig. 3b,d,f) and the impact of the treatments declined (Table 2). Microbial C and $\mathrm{N}$ immobilization rates were enhanced by higher temperatures and decreased with increasing moisture, sometimes even becoming negative, indicating a decline in the size of microbial biomass. In this second period, microbial $\mathrm{P}$ immobilization rate was significantly affected by temperature and moisture, but the linear regression was not significant (Tables 1 and 2). Accumulated microbial biomass $\mathrm{P}$ varied between 0.26 and $0.6 \mathrm{~g} \mathrm{P} \mathrm{kg}^{-1}$. The accumulated microbial after 48 days biomass $\mathrm{P}$ strongly increased with moisture (Fig. 4).

Net $\mathrm{P}$ and $\mathrm{N}$ mineralization and net nitrification rates

Net $\mathrm{P}$ mineralization rate depended more strongly on temperature than on the level of moisture and generally increased with temperature and moisture (Table 2). In the first period, net $\mathrm{P}$ mineralization rate increased with temperature at 50\% moisture (Fig. 5a). At 100 and $200 \%$ moisture, net $\mathrm{P}$ mineralization increased from 5 to $10^{\circ} \mathrm{C}$, but declined at 15 and $20^{\circ} \mathrm{C}$. In the second period, net $\mathrm{P}$ mineralization rate was generally lower and decreased with increasing temperature and moisture (Fig. $5 \mathrm{~b}$ and Table 2). Also, the effect of temperature and moisture was smaller. Net $\mathrm{P}$ mineralization decreased between 15 and $20^{\circ} \mathrm{C}$ for all moisture contents. 
Table 3 Decomposition constant $k$ (year ${ }^{-1}$ ), standard deviation between brackets $(n=5)$ and $r^{2}$ values for the single exponential decay model (Eq. 2)

\begin{tabular}{lllllllllllll}
\hline Temp & 5 & 5 & 5 & 10 & 10 & 10 & 15 & 15 & 15 & 20 & $\begin{array}{l}20 \\
100\end{array}$ \\
Moist & 50 & 100 & 200 & 50 & 100 & 200 & 50 & 100 & 200 & 50 & 200 \\
\hline$k$ avg & 0.09 & 0.19 & 0.32 & 0.20 & 0.27 & 0.38 & 0.33 & 0.43 & 0.51 & 0.50 & 0.59 & 0.57 \\
$k$ std & $(0.02)$ & $(0.04)$ & $(0.01)$ & $(0.07)$ & $(0.04)$ & $(0.06)$ & $(0.04)$ & $(0.02)$ & $(0.04)$ & $(0.04)$ & $(0.05)$ & $(0.01)$ \\
$r^{2}$ & 0.99 & 0.95 & 0.98 & 0.96 & 0.92 & 0.91 & 0.95 & 0.97 & 0.95 & 0.92 & 0.94 & 0.89 \\
\hline
\end{tabular}

For explanation of abbreviations, see caption of Fig. 1. Differences in $k$ values are significant $(P<0.05)$ between each couple of moisture contents at the same temperature (except at $20^{\circ} \mathrm{C}$ for $100 \%$ vs $200 \%$ ) and between each couple of temperatures at the same moisture content (except at $200 \%$ for $15^{\circ} \mathrm{C}$ vs $20^{\circ} \mathrm{C}$ )

Net $\mathrm{N}$ mineralization was affected by temperature and moisture conditions (Table 1). In the first incubation period, net $\mathrm{N}$ mineralization increased with temperature and decreased with increasing moisture (Table 2). At 50\% moisture, net $\mathrm{N}$ mineralization rate increased strongest between 5 and $10^{\circ} \mathrm{C}$, while at 100 and $200 \%$ moisture, net $\mathrm{N}$ mineralization increased strongest between 15 and $20^{\circ} \mathrm{C}$ (Fig. 5c). In the second period, the linear regression was not significant. Net $\mathrm{N}$ mineralization was negative for all three moisture contents at $20^{\circ} \mathrm{C}$ (Fig. 5d). Net nitrification rates were more strongly affected by temperature and increased with temperature and moisture in the first period (Table 2 and Fig. 5e). In the second period, net nitrification was the highest at $15^{\circ} \mathrm{C}$ and $200 \%$ moisture and the lowest at $20^{\circ} \mathrm{C}$ at all moisture contents (Table 2 and Fig. 5f).

\section{Discussion}

Litter decomposition rate increased with increasing temperature and increasing moisture condition. The percentage remaining of litter initial mass after 206 days ranged from $94.9 \%$ at $5^{\circ} \mathrm{C}$ and $50 \%$ moisture to $71.5 \%$ at $20^{\circ} \mathrm{C}$ and $200 \%$ moisture. Emmett et al. (2004) reported data from litterbag experiments with $C$. vulgaris litter in a dry heathland in Denmark, in a wet heathland in Wales, and in the Oldebroekse heide in The Netherlands where we sampled the litter for this experiment. They found a remaining amount of initial mass after 200 days of 73,82 , and $80 \%$, respectively. The litter incubated in the laboratory experienced constant temperature and moisture conditions, while litter incubated in a field experiment experienced a variety of temperature and moisture conditions.

The overall average mass remaining in this experiment, approximately $83 \%$, corresponded well with the range found in the field experiment. Emmett et al. (2004)
Fig. 2 Temperature response of (a and $\mathbf{b}) \mathrm{CO}_{2}$ respiration and (c and d) the metabolic quotient $\left(q \mathrm{CO}_{2}\right)$ from days 0 to 48 and days 48 to 206 . --- -- , $50 \%$ of moisture; - -,$- 100 \%$ of moisture; —o—, 200\% of moisture. Error bars indicate standard deviation $(n=5)$
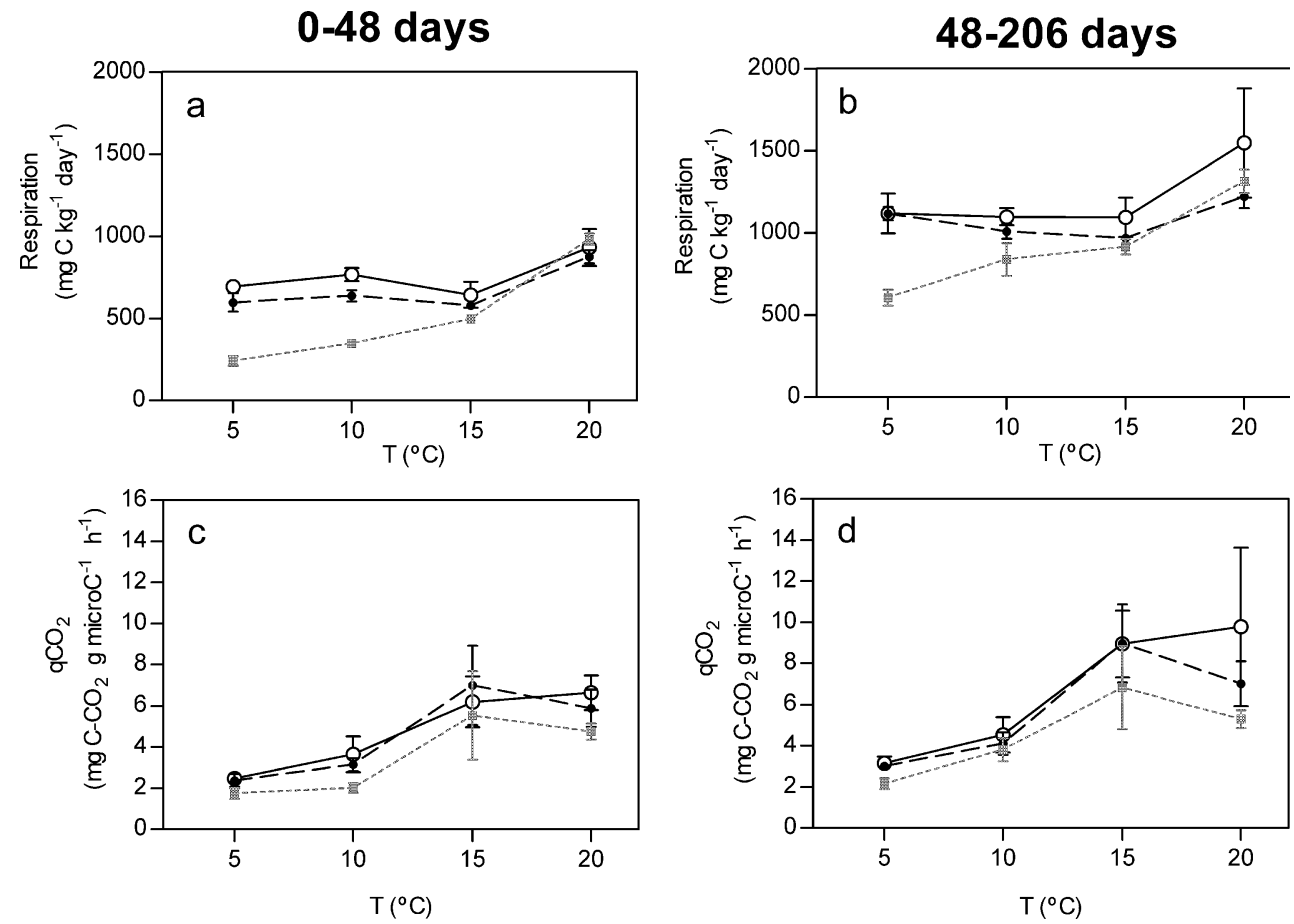
Fig. 3 Temperature response of (a and b) C immobilization, (c and d) $\mathrm{N}$ immobilization and (e and f) $\mathrm{P}$ immobilization from days 0 to 48 and days 48 to $206 .--1--, 50 \%$ of moisture; --, $100 \%$ of moisture; — ——, $200 \%$ of moisture. Note the different scales of the $y$-axes. Error bars indicate standard deviation $(n=5)$
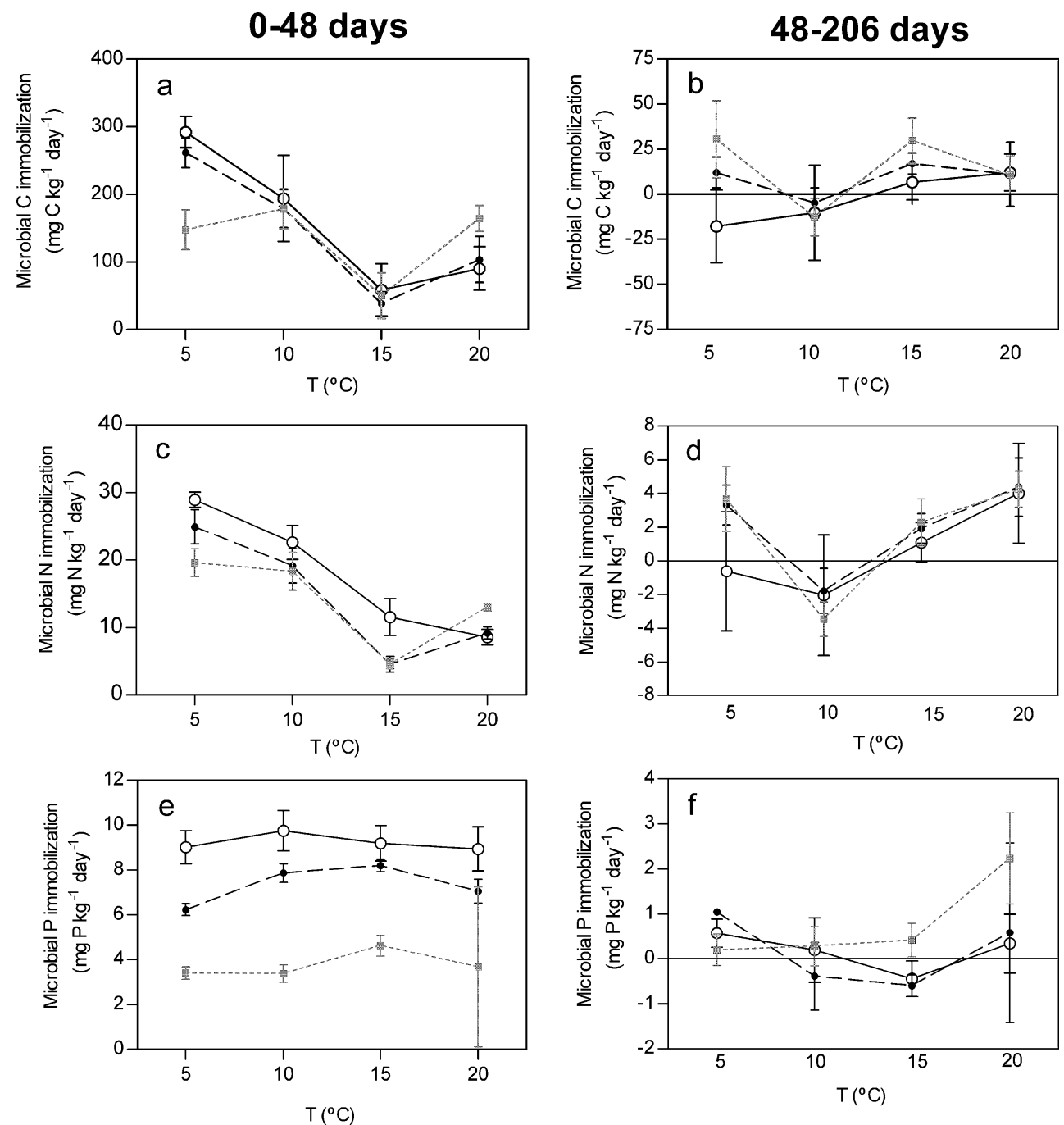

manipulated temperature and moisture with a nonintrusive field experiment. They induced 2 months summer droughts and increased temperature with $0.5-2.0^{\circ} \mathrm{C}$ on other experimental plots. The drought effect was only temporary and occurred in the sampling just after the drought. This is in line with our laboratory observations where continuous drought decreased the decomposition rate. From the field experiment it can be concluded that this effect is compensated after the drought, indicating that the chemical composition of the litter dominates the regulation of the mass loss. Emmett et al. (2004) found a general positive effect of warming in the Calluna sites. Their field warming as well as our laboratory warming was constant and both increased the decomposition rate, $q \mathrm{CO}_{2}$ and the respiration rate, all variables connected to $\mathrm{C}$ mineralization.

Initial microbial growth was high and the size of the microbial biomass $\mathrm{C}\left(4-16 \mathrm{~g} \mathrm{C} \mathrm{kg}^{-1}\right), \mathrm{N}(0.4-1.7 \mathrm{~g} \mathrm{~N}$ $\left.\mathrm{kg}^{-1}\right)$, and $\mathrm{P}\left(0.26-0.61 \mathrm{~g} \mathrm{Pg}^{-1}\right)$ increased to a community size found in other studies on heathland ecosystems (Jonasson et al. 1996; Schmidt et al. 1999;

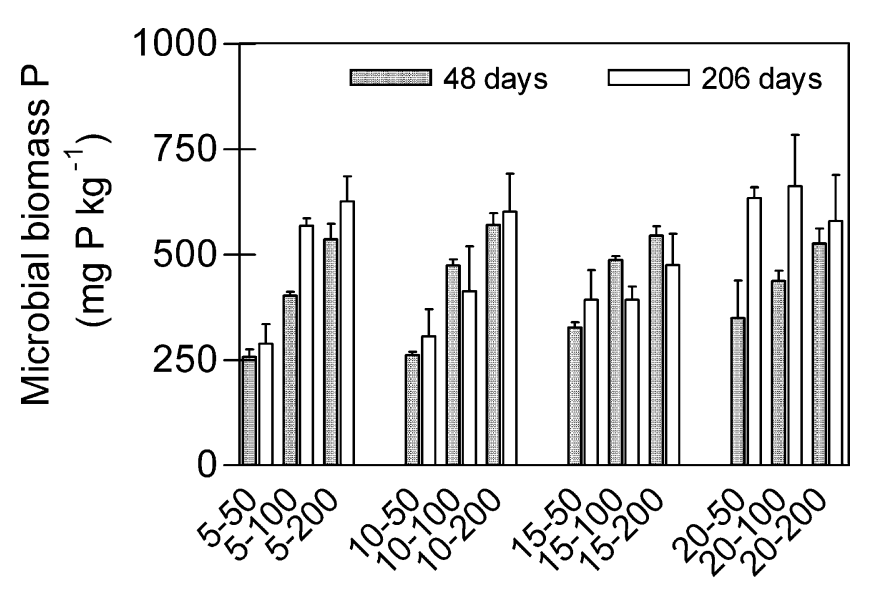

Temperature $\left({ }^{\circ} \mathrm{C}\right)$ and Moisture (\%)

Fig. 4 Microbial biomass $\mathrm{P}$ in $\mathrm{mg} \mathrm{kg}^{-1}$ after 48 and 206 days for all temperature and moisture conditions. Error bars indicate standard deviation $(n=5)$ 
Fig. 5 Temperature response of (a and $\mathbf{b})$ net $\mathrm{P}$ mineralization, (c and d) net $\mathrm{N}$ mineralization, and (e and $\mathbf{f})$ net nitrifications from days $(0$ to 48 and days 48 to 206.--口-- , $50 \%$ of moisture; -., $100 \%$ of moisture; - - - $200 \%$ of moisture. Note the different scales of the $y$-axes. Error bars indicate standard deviation $(n=5)$
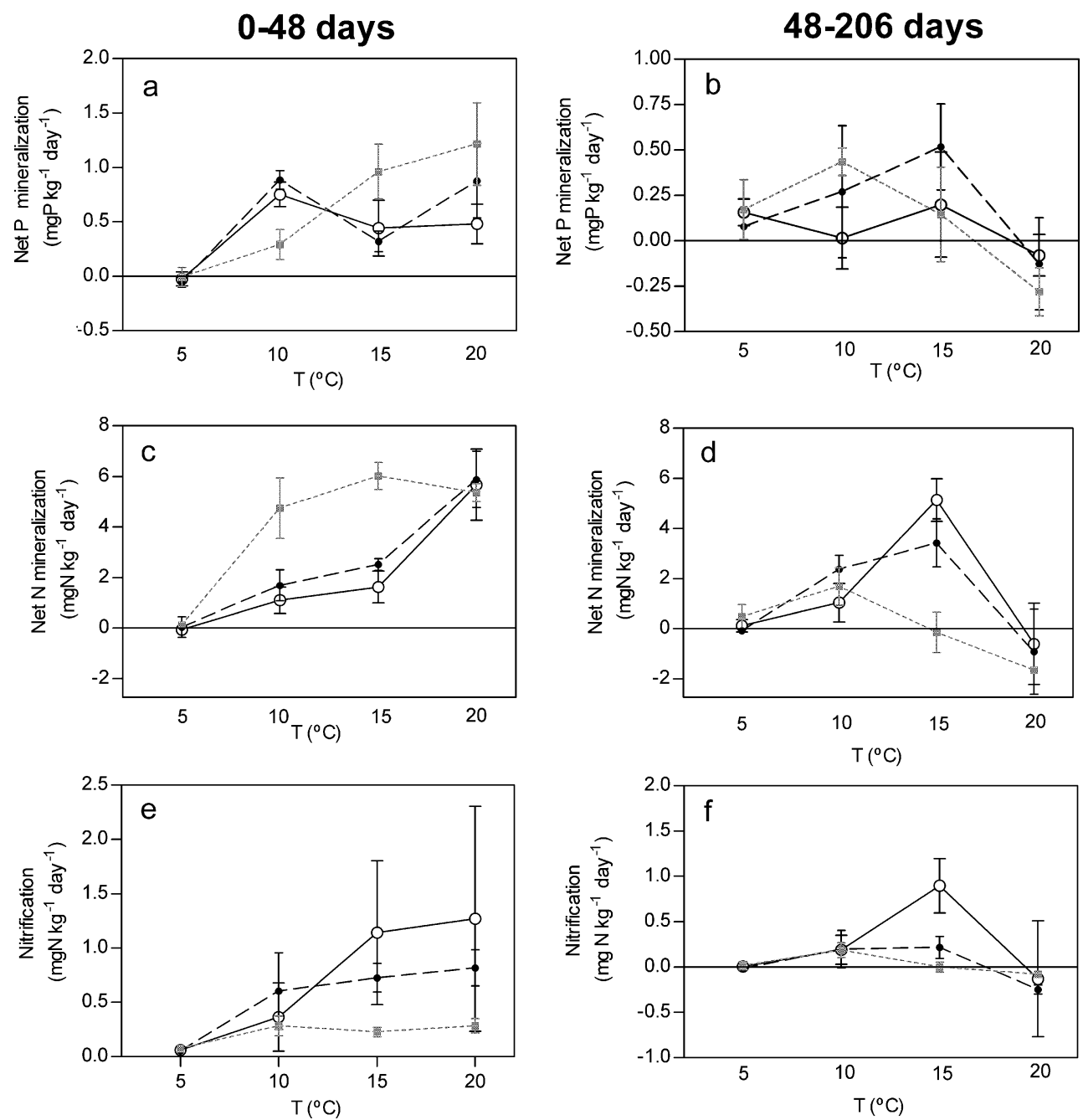

Jensen et al. 2003). In the first decomposition period, the microbial $\mathrm{C}$ and $\mathrm{N}$ immobilization rates were more strongly controlled by temperature, while $\mathrm{P}$ immobilization rate was more strongly affected by moisture. A possible explanation for this different response could be related to the low $\mathrm{P}$ availability in the $\mathrm{P}$-poor $C$. vulgaris litter. At low soil water content, diffusion of soluble substrates is reduced (Griffin 1981a) and/or microbial mobility and consequent access to substrate declines (Griffin 1981b; Killham et al. 1993). This could affect the mineralization and immobilization of the limiting nutrient $(\mathrm{P})$ more strongly than the availability of the more abundant nutrients ( $\mathrm{C}$ and $\mathrm{N})$. Values of volumetric water content below which microbial activity declines in mineral soil are not comparable with values in litter because fresh litter has a much larger pore volume than mineral soil and therefore has a far higher air/mass ratio (Schaap et al. 1997). However, mechanisms involved are most likely comparable to those in litter.

In the second decomposition period, microbial growth rate decreased significantly at all temperatures and moisture contents. The largest decrease was found at the largest moisture content, which showed the highest immobilization during the first period. A possible explanation for the decreased growth rate is the lack of available P. There might be two possible mechanisms involved. First, an indirect moisture effect: a higher moisture content of the litter material resulted in a high $\mathrm{P}$ immobilization rate (at the beginning of the second period 74 to $85 \%$ of total $\mathrm{P}$ was incorporated in microbial $\mathrm{P}$ pool, at $200 \%$ moisture) and in almost complete $\mathrm{P}$ depletion of the litter. Second, a direct moisture effect: low moisture content limited microbial $\mathrm{P}$ immobilization and mineralization (at the beginning of second period only 41 to $50 \%$ of total $\mathrm{P}$ was incorporated in microbial $\mathrm{P}$, at $50 \%$ moisture).

Plant growth relies completely on competition with microbes for $\mathrm{P}$ in this low-P environment. The results show that changes in temperature and moisture largely determine the amount of $\mathrm{P}$ immobilized in microbial biomass, unavailable for plants. After 208 days, this accumulated amount of immobilized $\mathrm{P}$ in microbes varies from 0.26 to $0.61 \mathrm{~g} \mathrm{P} \mathrm{kg}^{-1}$, at 42 and $100 \%$, respectively. 
Microbial $\mathrm{C}$ and $\mathrm{N}$ immobilization rate decreased with increasing temperature, resulting in a smaller microbial biomass at higher temperature (Fig. 5a,b). Respiration rate generally increased with temperature, especially between 15 and $20^{\circ} \mathrm{C}$. Consequently, the $q \mathrm{CO}_{2}$ increased with temperature, especially between 5 and $15^{\circ} \mathrm{C}$ (Fig. 2c,d), which indicated a decrease in microbial $\mathrm{C}$ utilization efficiency. Jonasson et al. (2004) also reported higher soil microbial biomass in soil samples incubated for 22 weeks at $10^{\circ} \mathrm{C}$ than at $12^{\circ} \mathrm{C}$, but higher $\mathrm{CO}_{2}$ respiration rates at $12^{\circ} \mathrm{C}$ than at $10^{\circ} \mathrm{C}$, resulting in a higher $q \mathrm{CO}_{2}$ at $12^{\circ} \mathrm{C}$. According to Pohhacker and Zech (1995), microbial biomass is very sensitive for high temperatures and high respiration rates can indicate a stressed microbial community.

Higher temperature can increase the energy demand of the microbes at the expense of the size and growth rate of the population (Pohhacker and Zech 1995). Nutrient stress, other than $\mathrm{C}$ limitation stress, has also been reported to result in a higher metabolic quotient (Wardle 1993; Wardle and Ghani 1995). It has been proposed that this is a result of diminished importance of conserving $\mathrm{C}$ resources as other nutrients become limiting (Wardle 1993). The increase in metabolic quotient with higher temperatures could therefore also indicate increased stress through decreased $\mathrm{P}$ availability.

From this study it is difficult to distinguish between the effect of temperature and the effect of decreased $P$ availability; however, the similar metabolic quotient at $20^{\circ} \mathrm{C}$ compared to $15^{\circ} \mathrm{C}$ could indicate that at least at these temperatures decreased $\mathrm{P}$ availability was more important. However, it is also possible that the similar metabolic quotient at $20^{\circ} \mathrm{C}$ compared to $15^{\circ} \mathrm{C}$ indicates increased C-use efficiency associated with the loss of easily degradable substrates, as the litter was more decomposed at $20^{\circ} \mathrm{C}$ than at $15^{\circ} \mathrm{C}$ (Wardle 1993; Dilly and Munch 1996).

Opposite responses in $\mathrm{N}$ and $\mathrm{P}$ transformation rates between the two periods were found. Net $\mathrm{N}$ mineralization rate increased between 15 and $20^{\circ} \mathrm{C}$ in the first period, but decreased in this interval in the second period (Fig. 5c,d). The decrease in net $\mathrm{N}$ mineralization rate was accompanied by an increase in net $\mathrm{N}$ immobilization rate. This same process occurred with net $\mathrm{P}$ mineralization: net $\mathrm{P}$ mineralization rate decreased between 15 and $20^{\circ} \mathrm{C}$ in the second incubation period, but was accompanied by an increase in $\mathrm{P}$ immobilization. Evidently, the balance between mineralization and immobilization depended on the stage of litter decomposition and microbial demand.

In the first 0-48 days, net $\mathrm{N}$ and $\mathrm{P}$ mineralization rate and nitrification rate increased with temperature. Rustad et al. (2001) also reported increased net $\mathrm{N}$ mineralization in response to experimental ecosystem warming in a metaanalysis on data from high (latitude and altitude) tundra, low tundra, grasslands, and forests. In this study, net $\mathrm{P}$ mineral- ization rate increased with moisture, while net $\mathrm{N}$ mineralization decreased with moisture from 0 to 48 days. A simultaneous decline in moisture content associated with increasing temperature in the field could therefore result in increased net $\mathrm{N}$ mineralization rate. However, it depends on the decline in moisture content associated with the increase in temperature what the effect on net $\mathrm{P}$ mineralization will be.

With the use of Table 2 the maximum decline in moisture content that would still result in net $\mathrm{P}$ mineralization can be calculated. In Table 2, the coefficients $t$ and $m$ for net $\mathrm{P}$ mineralization ( $\mathrm{P}$ min) from $0-48$ days were respectively $5.23 \times 10^{-2}$ and $1.30 \times 10^{-2}$. Coefficient $t$ divided by coefficient $m$ amounts to 4.02 , which means that if temperature increases with $1{ }^{\circ} \mathrm{C}$, moisture can decrease with a maximum of $40.2 \%$ (to obtain unit increase in temperature and moisture, moisture was divided by 10) before the increase in temperature, and consequent increase in net $\mathrm{P}$ mineralization is counteracted by decreased $\mathrm{P}$ mineralization due to decreased moisture. This indicates that if temperature increases with $1{ }^{\circ} \mathrm{C}$ and moisture does not decrease with more than $40.2 \%$ during the very early stage of litter decomposition, net $\mathrm{P}$ mineralization rate is enhanced.

\section{Conclusions}

The effect of temperature and moisture on microbial nutrient transformations was strongest during the first 48 days of fresh $C$. vulgaris litter decomposition. In this period, the $\mathrm{CO}_{2}$ respiration rate, $q \mathrm{CO}_{2}$, microbial $\mathrm{C}$ and $\mathrm{N}$ immobilization, net $\mathrm{P}$ mineralization, net $\mathrm{N}$ mineralization and net nitrification rates were controlled predominantly by temperature conditions, while microbial $\mathrm{P}$ immobilization rate was more strongly affected by moisture. The variation in climatic factors imposed on this low P Calluna litter showed a large variation in microbial $\mathrm{P}$ immobilization. As plants strongly compete with microbes for this $\mathrm{P}$, this experiment indicates that climate change endangers the sustainability of these ecosystems.

Acknowledgments We wish to thank Piet Wartenbergh, Ton van Wijk, and Leo Hoitinga for their advice and assistance with the laboratory analyses, and Koos Verstraten for his valuable suggestions during the preparation of the manuscript. We also thank Alwyn Sowerby for her help on the English language. This research was funded by EU under the project VULCAN (Contract EVK2-CT-200000094) and the University of Amsterdam.

\section{References}

Anderson TH, Domsch KH (1990) Application of ecophysiological quotients $\left(q \mathrm{CO}_{2}\right.$ and $\left.q \mathrm{D}\right)$ on microbial biomass from soils of different cropping histories. Soil Biol Biochem 22:251-255 
Beier C, Emmett B, Gundersen P, Tietema A, Peñuelas J, Estiarte M, Gordon C, Gorissen A, Llorens L, Roda F, Williams D (2004) Novel approaches to study climate change effects on terrestrial ecosystems in the field: drought and passive nighttime warming. Ecosystems 7:583-597

Brookes PC, Powlson DS, Jenkinson DS (1982) Measurement of microbial biomass phosphorus in soil. Soil Biol Biochem 14:319-329

Brookes PC, Landman A, Pruden G, Jenkinson DS (1985) Chloroform fumigation and the release of soil nitrogen: a rapid direct extraction method to measure microbial biomass nitrogen in soil. Soil Biol Biochem 17:837-842

Dilly O, Munch J (1996) Microbial biomass content, basal respiration and enzyme activities during the course of decomposition of leaf litter in a black alder (Alnus glutinosa (L.) Gaertn.) forest. Soil Biol Biochem 28:1073-1081

Emmett BA, Beier C, Estiarte M, Tietema A, Kristensen HL, Williams D, Peñuelas J, Schmidt I, Sowerby A (2004) The response of soil processes to climate change: results from manipulation studies of shrublands across an environmental gradient. Ecosystems 7:625-637

FAO (1998) World reference base for soil resources, World Soil Resources Report 84, Rome Italy

Green RN, Trowbridge RL, Klinka K (1993) Towards a taxonomic classification of humus forms. Forest Science Monograph 29

Griffin DM (1981a) Water potential as a selective factor in the microbial ecology of soils. In: Parr JF, Gardner WR, Elliott LF (eds) Water potential relations in soil microbiology. SSSA Special Publication no. 9. SSSA, Madison, WI, pp 141-151

Griffin DM (1981b) Water and microbial stress. In: Alexander M (eds) Advances in microbial ecology. Plenum, New York, pp 91-136

Heil DW, Bobbink R (1993) Impact of atmospheric nitrogen deposition on dry deposition on dry heathlands. A stochastic model simulating competition between Calluna vulgaris and two grass species. In: Aerts RH, Heil GW (eds) Heathlands: patterns and processes in a changing environment. Kluwer, Dordrecht, pp 181-200

Howard DM, Howard PJA (1993) Relationships between $\mathrm{CO}_{2}$ evolution, moisture content and temperature for a range of soil types. Soil Biol Biochem 25:1537-1546

Jensen KD, Beier C, Michelsen A, Emmett B (2003) Effects of experimental drought on microbial processes in two temperate heathlands at contrasting water conditions. Appl Soil Ecol 24:165-176

Jonasson S, Michelsen A, Schmidt IK, Nielsen EV, Callaghan TV (1996) Microbial biomass C, N and P in two arctic soils and responses to addition of NPK fertilizer and sugar: Implications for plant nutrient uptake. Oecologia 106:507-515

Jonasson S, Michelsen A, Schmidt IK, Nielsen EV (1999) Responses in microbes and plants to changed temperature, nutrient, and light regimes in the arctic. Ecology 80:1828-1843

Jonasson S, Castro J, Michelsen A (2004) Litter, warming and plants affect respiration and allocation of soil microbial and plant $\mathrm{C}, \mathrm{N}$ and $\mathrm{P}$ in arctic mesocosms. Soil Biol Biochem 36:1129-1139

Killham K, Amato M, Ladd JN (1993) Effect of substrate location in soil and soil pore-water regime on carbon turnover. Soil Biol Biochem 25:57-62

Kirschbaum MUF (1995) The temperature dependence of soil organic matter decomposition and the effect of global warming on soil organic C storage. Soil Biol Biochem 27:753-760

Koerselman W, Meuleman AFM (1996) The vegetation N:P ratio: a new tool to detect the nature of nutrient limitation. J Appl Ecol 33:1441-1450

Leirós MC, Trasar-Cepeda C, Seoane S, Gil-Sotres F (1999) Dependence of mineralization of soil organic matter on temperature and moisture. Soil Biol Biochem 31:327-335

Levene H (1960) Robust tests for equality of variances. In: Olkin I (eds) Contributions to probability and statistics: essays in honor of Harold Hotelling. Stanford University Press, pp 278-292
McHale PJ, Mitchell MJ, Bowles FP (1998) Soil warming in a northern hardwood forest: trace gas fluxes and leaf litter decomposition. Can J Forest Res 28:1365-1372

Murphy J, Riley JP (1962) A modified single solution method for the determination of phosphate in natural waters. Anal Chim Acta 27:31-36

Olsen SR, Cole CV, Watanabe FS, Dean LA (1954) Estimation of available phosphorus in soils by extraction with sodium bicarbonate. United States Department of Agriculture Circular

Parsons AWJ, Wookey PA, Press MC, Callaghan TV, Lee JA (1994) Growth response of four sub-artic dwarf shrubs to simulated environmental change. J Ecol 82:307-318

Peterjohn WT, Melillo JM, Steudler PA, Newkirk KM, Bowles ST, Aber JD (1994) Responses of trace gas fluxes and N availability to experimentally elevated soil temperatures. Ecol Appl 4:617-625

Pohhacker R, Zech W (1995) Influence of temperature on $\mathrm{CO}_{2}$ evaluation. Microbial biomass $\mathrm{C}$ and metabolic quotient during the decomposition of two humic forest horizons. Biol Fertil Soils 19:239-245

Press MC, Potter JA, Burke MJW, Callaghan TV, Lee JA (1998) Responses of a sub-arctic dwarf shrub community to simulated environmental change. J Ecol 86:315-327

Rustad LE, Fernandez IJ (1998) Experimental soil warming effects on $\mathrm{CO}_{2}$ and $\mathrm{CH}_{4}$ flux from a low elevation spruce fir forest soil in Maine, USA. Global Change Biol 4:597-607

Rustad LE, Campbell JL, Marion GM, Norby RJ, Mitchell MJ, Hartley AE, Cornelissen JHC, Gurevitch J (2001) A metaanalysis of the response of soil respiration, net nitrogen mineralization and aboveground plant growth to experimental ecosystem warming. Oecologia 126:543-562

Schaap MG, Bouten W, Verstraten JM (1997) Forest floor water content dynamics in a Douglas fir stand. J Hydrol 201:367-383

Schmidt IK, Jonasson S, Michelsen A (1999) Mineralization and microbial immobilization of $\mathrm{N}$ and $\mathrm{P}$ in arctic soils in relation to season, temperature and nutrient amendment. Appl Soil Ecol $11: 147-160$

Schmidt IK, Tietema A, Williams D, Gunderson P, Beier C, Emmett BA, Estiarte M (2004) Soil solution chemistry and element fluxes in three european heathlands and their responses to warming and drought. Ecosystems 7:638-649

SPSS Inc (2001) SPSS Base 11.0 User's Guide. Chicago, IL, USA

Swift MJ, Heal OW, Anderson JM (1979) Decomposition in terrestrial ecosystems. Studies in Ecology, vol 5. Blackwell Scientific Publications, Oxford, UK

Van Meeteren MJM (2005) Heathland ecosystem functioning under climate change (Ph.D. thesis). Universiteit van Amsterdam, The Netherlands

Vance ED, Brookes PC, Jenkinson DS (1987) An extraction method for measuring soil microbial biomass C. Soil Biol Biochem 19:703-707

Wardle DA (1993) Changes in the microbial biomass and metabolic quotient during leaf litter succession in some New Zealand forest and scrubland ecosystems. Funct Ecol 7:436-455

Wardle DA, Ghani A (1995) A critique of the microbial metabolic quotient $\left(q \mathrm{CO}_{2}\right)$ as a bioindicator of disturbance and ecosystem development. Soil Biology and Biochemistry 27:1601-1610

Wookey PA, Welker JM, Parsons AN, Press MC, Callaghan TV, Lee JA (1994) Differential growth, allocation and photosynthetic responses of Polygonum viviparum to simulated environmental change at a high arctic polar semidesert. Oikos 70:131-139

Wu J, Joergensen RG, Pommerening B, Chaussod R, Brookes PC (1990) Measurement of soil microbial biomass C by fumigationextraction: an automated procedure. Soil Biol Biochem 22:11671169 